\title{
Pondering a Career Change? Become a (Greatly Needed) Physical Science Teacher! Julie Nucci
}

People who study biology, physics, or chemistry may have in the back of their minds that they could someday become a teacher. Far fewer materials researchers or engineers probably entertain such thoughts during their college years or their careers. But they should think again. There is already a critical need for physical science teachers and this need is predicted to sharply increase. The 2007 report Rising Above the Gathering Storm: Energizing and Employing America for a Brighter Economic Future, generated by an elite panel of U.S. industrials and academics, sends the warning flags flying. This report contrasts the great domestic need for scientists and engineers with the lack of interested and qualified students to meet this demand. A key barrier identified in the report is the poor preparation of K-12 math and science teachers. Table I reveals the severely insufficient educational background of science and math teachers. That $93 \%$ of middle school physical science teachers have either no certification or have not majored in science is astonishing. How can we expect teachers who have no deep understanding of the material they are teaching to inspire our youth?

This is not the only problem; there are also chronic shortages in the teaching workforce. As baby-boomers retire or leave the profession, the nation's schools will need to find 1.7-2.7 million new teachers to replace them over the next decade. About 200,000 of these positions will be for secondary science and mathematics classrooms. Training and retaining highly qualified science teachers is key to improving the nation's educational system. The Gathering Storm report states, "The critical lack of technically trained people in the United States can be traced directly to poor K-12 mathematics and science instruction. Few factors are more important than this if the United States is to compete successfully in the 21st century."

Materials researchers who are called from within to teach, but have yet to respond, should seriously consider this possible career change. The need is dire and what materials researchers have to offer is tremendous. Those who hear the call are not alone. In fact, the Woodrow Wilson National Fellowship Foundation sponsored a February 2008 survey of 2292 individuals and identified 1110 respondents as potential teachers. Eligible candidates were 24-60 years old and had at least a bachelor's degree. The

\begin{tabular}{lcc}
\hline \multicolumn{3}{c}{$\begin{array}{c}\text { Table I. Students in U.S. Public Schools Taught by Teachers with } \\
\text { No Major or Certification in the Subject Taught, 1999-2000 }\end{array}$} \\
\hline Discipline & Grades 5-8 & Grades 9-12 \\
English & $58 \%$ & $30 \%$ \\
Mathematics & $69 \%$ & $31 \%$ \\
Physical Science & $93 \%$ & $63 \%$ \\
Biology-Life Sciences & - & $45 \%$ \\
Chemistry & - & $61 \%$ \\
Physics & - & $67 \%$ \\
Physical Education & $19 \%$ & $19 \%$ \\
\hline
\end{tabular}

Source: Table 5-1 from Rising Above the Gathering Storm: Energizing and Employing America for a Brighter Economic Future, (The National Academies Press, Washington, D.C. 2007), www.nap.edu (accessed February 2009).

\section{Table II. Important Reasons to Consider Becoming a Teacher}

Very Important (\%)

I enjoy working with young people and want to help them succeed 65

Teaching would give me a way to give back and help improve society 58

I like the flexibility that teaching would allow, including having summers off 41

Teaching would be a new challenge that I would enjoy taking on $\quad 41$

I am particularly interested in a specific subject and would enjoy the 40 opportunity to learn more about it and share this knowledge with others

Teaching would offer personal satisfaction and fulfillment that I have not experienced in other fields

The health and retirement benefits are appealing to me

A teacher changed my life, and I would like to have that impact on others

The job security is appealing to me

31

A close friend or family member told me that I would make a good teacher

27

20

Source: "Teaching as a Second Career," (The Woodrow Wilson National Fellowship Foundation, Princeton, 2008), www.woodrow.org (accessed February 2009).

results are reported in the September 2008 report "Teaching as a Second Career" (www.woodrow.org/news/ news_items/WW_2ndCareerTeachers 0908.php; accessed February 2009). A companion document, also released in September 2008 and found at the same Web site, is entitled "Encore Performances: Tapping the Potential of MidCareer and Second Career Teachers."

Mid-career materials professionals would bring scientific excellence, maturity, enhanced relevance, and practical appli-

INTERFACES seeks articles featuring the people and profession of materials. Send proposals to Bulletin@mrs.org. cations to their classrooms. What better way could there be to improve the public understanding of materials science and engineering than to have materials researchers teaching middle school physical science, high school physics, and high school chemistry? But this is not just about promoting materials science and engineering among school-aged children; it is about materials researchers committing energy, time, and passion to raising the standard of education and the advancement of young people. The survey results detailed in "Teaching as a Second Career" show that potential teachers are not mainly motivated by the need to promote U.S. competitiveness, as outlined in the Gathering Storm report, but by altruism and community-driven aspects of teaching. Table II details addi- 
tional reasons why these 1100 people are interested in teaching.

The most important deterrents to considering teaching as a second profession are the low salary and lack of prestige associated with teaching. A full $68 \%$ of potential teachers believe that a salary decrease would accompany a career change into teaching. Hopefully the new administration will recognize the significance of these barriers to the goal of producing high quality science teachers. Findings indicate that more people would consider teaching as a second career if a starting salary of $\$ 50,000$ were assured, in addition to the expectation of quality training and support. A table that details the characteristics of alternative teacher certification programs by state is found at the end of the Encore Performances report. This table includes the program goals, focus, oversight, length, and entry requirements. Generally, alternative certification programs last one to two years.

The cost associated with the additional education needed for certification is also a barrier to potential teachers. To address this concern, with an additional focus on assisting schools that exhibit the greatest need, The Woodrow Wilson National Fellowship Foundation's Lenora Annenberg Teaching Fellowship was launched in December of 2007. This fellowship provides an equivalent of a "Rhodes Scholarship" for potential teachers by offering a $\$ 30,000$ salary for exceptional candidates to complete a one year master's program at Stanford University, The University of Washington, The University of Pennsylvania, or the University of Virginia. Information regarding this fellowship can be found at Web site www. woodrow.org/news/news_items/WW_ TeachingFellowship_NATL_Dec07.php.

In my current position as director of Education Programs for the Center for Nanoscale Systems (CNS) at Cornell University, I run the CNS Institute for Physics Teachers. I am continually impressed by the tremendous dedication of high school physics teachers and the passion with which they approach their profession. I asked seven physics teachers, who chose teaching as a second career, several questions that explored their previous careers, their reasons for wanting to teach, their educational background, and their opinions of their new profession. I was moved by their search for balance between professional and personal fulfillment, their motivation to teach, and the dedication with which they pursue their new career. It is worth sharing these stirring personal stories to provide insight into what it is that makes a great teacher.

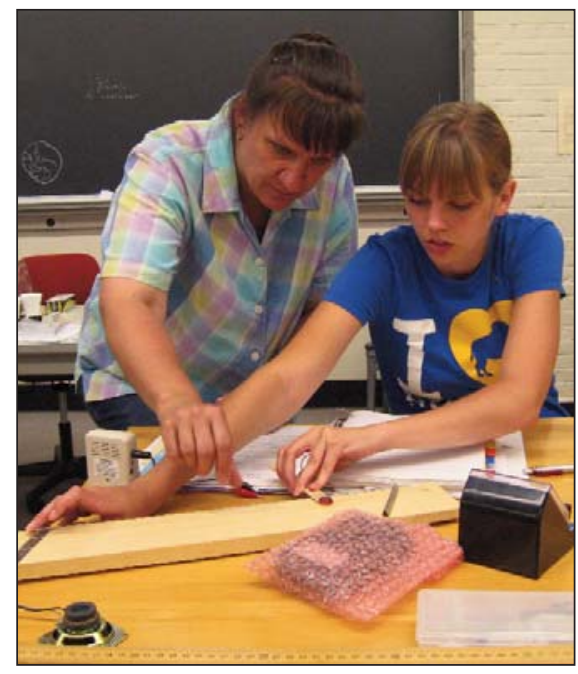

Aileen Svereika (left) and Stephanie Metz learn "Physics on a Guitar." (Credit: Angela Poh Woon Ying)

Aside from graduate degrees in education mandated by New York State, these seven teachers hold bachelor's/master's degrees in physics, chemistry, and engineering, as well as one teacher who holds a doctor of optometry degree. In their first careers, these teachers were engineers in industry, a research technician, a deputy commander in the Navy, a Lieutenant Colonel in the Air Force, and an optometrist.

Regarding the demand for teachers highlighted in the literature just cited, one teacher cautioned, "There may be a shortage of physics teachers in the United States, but the shortage is very dependent on location. Most people who are looking to change careers would prefer to stay in the same locale and not uproot themselves for a teaching job." Indeed, the statistics do show a higher need for teachers in the inner cities and rural areas than in the suburbs. This explains why the Annenberg Fellowship seeks to train people to teach specifically in high need areas.

Consider the different skill set needed to be successful in science or engineering than in teaching. Aileen Svereika, who has five years of teaching experience after a 16-year career in industry noted that, "teaching is intensively people-oriented at all levels of interaction with students, parents, peer teachers, teacher's aides, and administrators. There is no such thing as your own laboratory that you can retreat to for solace that you might have been accustomed to in your former career. Knowing your subject well is a necessary but not sufficient condition to being an effective teacher. Teaching is all about making connections with students and not just content knowledge."

In response to a question about their job satisfaction as a teacher versus in their previous careers, teachers were as satisfied or more satisfied with their current profession, although the loss of income that accompanied their career change was consistently noted. When asked about training, all but one respondent described roughly a one-to-two-year alternative certification program, in agreement with the Encore Performances data.

The reasons these individuals gave for becoming a teacher included a desire to work with young people, a lack of advancement opportunities in their previous profession, and the compatibility of teaching with raising a family, among others. Linda Gulden, a former IBM engineer, said, "Teaching chose me." This seems to be a common sentiment among second career teachers. When asked why he chose teaching, Glenn Elliott, a former submarine officer with 26 years experience in the U.S. Navy, responded, "Of all the duties I had as a nuclear trained [submarine] officer, training my men to be the best they could was my favorite. I also wanted to serve my community closer to home." After 23 years as an Air Force Officer, Bob Proctor said, "In the Air Force, I had achieved the rank of Lieutenant Colonel and I was very much involved with the space program as a propulsion and

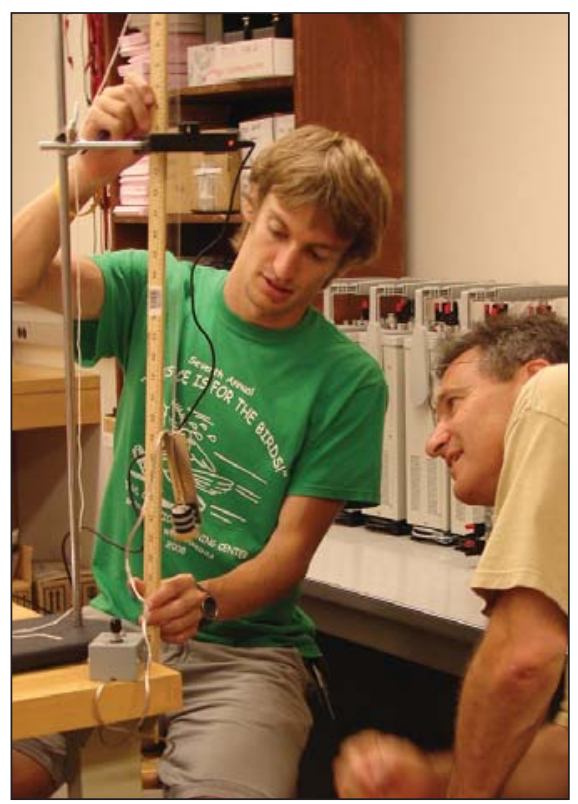

Chris Sheaffer (left) and Lou Gittler learn the "Resonance" laboratory project. (Credit: Angela Poh Woon Ying) 
mechanical/structural engineer. I was responsible for many developmental projects with a host of aerospace contractors across the country, which mandated a lot of travel time away from home. My home was a place where I had a washer, dryer, and an iron and my life was one engineering adventure after another. In retirement, I was not ready to slow down but I wanted to connect with all the experiences that I missed in the first 23 years. I decided I was leaving the aerospace environment I enjoyed because I wanted to connect with people and the more human side of life."

When asked what advice these teachers would give scientists or engineers pondering changing careers to become a teacher, Patricia Spackman, who left a career as a consulting engineer, said, "Teaching is a very time-consuming job that has great rewards." Howard Spergel said his job satisfaction as a teacher is much greater than during his engineering career, but warned that "teaching is a lot harder than you can imagine. Be prepared to spend many hours beyond the school day preparing, especially in the beginning. Don't do it because you think it is a cushy 9 a.m.-3 p.m. job with summers off." Elliot, in his ninth year of public high school teaching, also said, "It gets better and better with every year."

Teaching clearly requires great dedication, especially in the early years, and the transition to teaching may not be an easy one. Aileen Svereika eloquently described how she coped during this critical time, "Treat yourself just as you treat your students: set high expectations, but give time to achieve those standards. I think it is important to see yourself as a co-learner with your students. Albeit, you are not learning the same subject, but everyday you are learning from your students how to become a more effective teacher. This teaching model of 'continual improvement,' 'lifelong learner,' 'learning by doing,' has many aspects from my former career-I am doing personal educational research every day I teach!"

In closing, Lou Gittler, an optometrist who practiced for 20 years before becoming a teacher, offered concise and to-thepoint advice to potential teachers: "(1) Make sure you love kids. (2) Feel passionate about the subject you teach. (3) Don't do it for the perks, vacations, etc. Doing a job you don't enjoy 180 days a year is a waste of your time, and it is unfair to the kids. They know a miserable teacher when they see one. (4) Teaching is the hardest thing I have ever done. It is also the most rewarding."

Julie Nucci is director of Education Programs of Cornell University's Center for Nanoscale Systems.

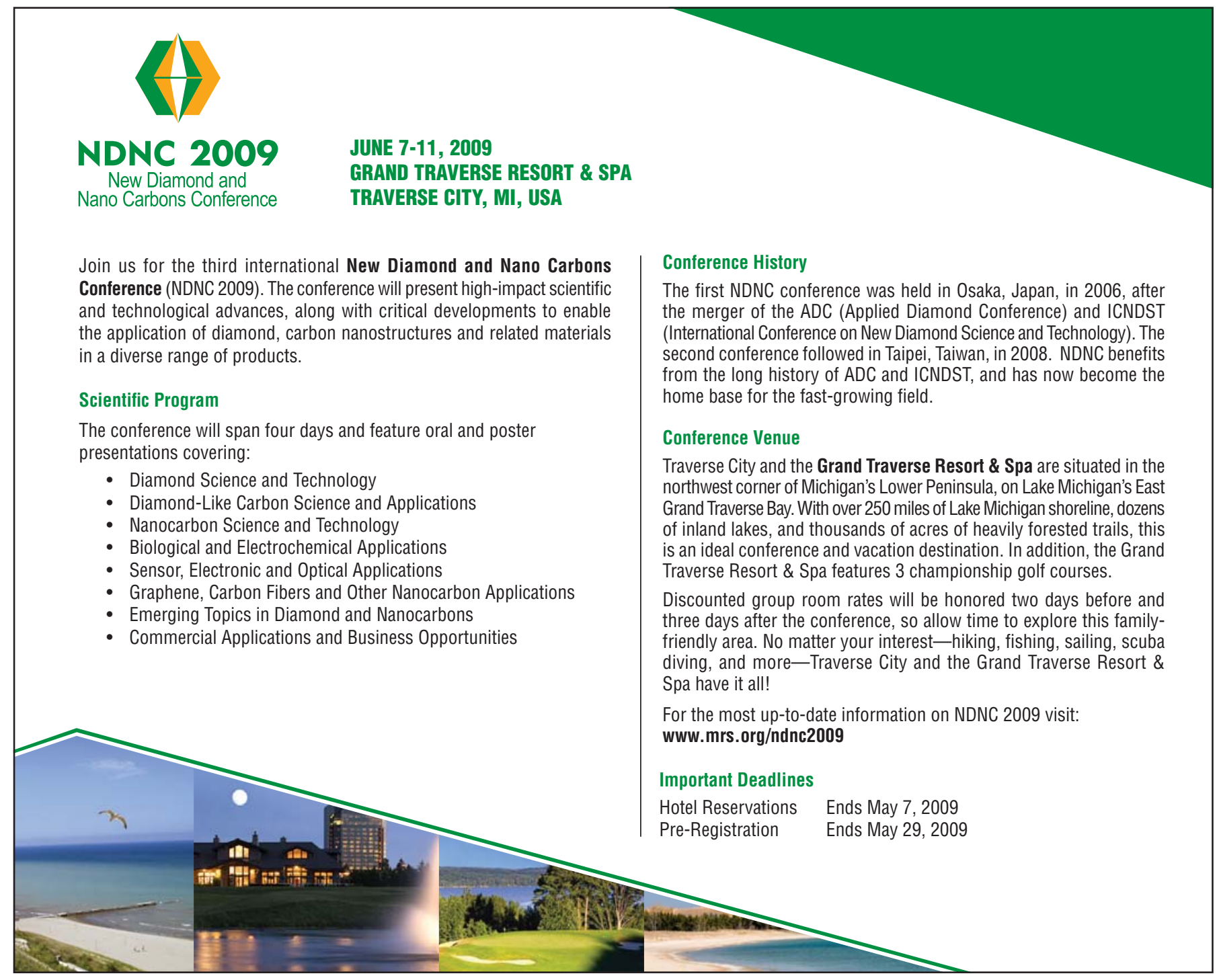

